\title{
Monitoring, Assessment and Management of Forest Insect Pests and Diseases
}

\author{
Won Il Choi ${ }^{1}$ and Young-Seuk Park ${ }^{2,3, *(1)}$ \\ 1 Division of Forest Ecology and Climate Change Division, National Forest Research Institute, Dongdaemun, \\ Seoul 02445, Korea; wchoi71@korea.kr \\ 2 Department of Biology, Kyung Hee University, Dongdaemun, Seoul 02447, Korea \\ 3 Department of Life and Nanopharmaceutical Sciences, Kyung Hee University, Dongdaemun, \\ Seoul 02447, Korea \\ * Correspondence: parkys@khu.ac.kr; Tel.: +82-2-961-0946
}

Received: 23 September 2019; Accepted: 27 September 2019; Published: 3 October 2019

check for updates

\begin{abstract}
Forest pests are one of the most important factors disturbing forest ecosystems, by impacting forestry economy, ecosystem services, biodiversity, and sustainable ecosystem management. Monitoring the occurrence of forest pests offers clues to understand their impacts on the forest ecosystem and develop a sustainable ecosystem management strategy. This special issue is designed to create a better understanding of the changes and impacts of forest pests according to forest changes, caused by natural or anthropogenic causes. There are 13 papers published in this special issue, covering several issues concerning forest pests. Two of the papers reviewed the changes in forest pests in Korea or Poland. The remaining twelve papers covered issues concerning the monitoring, assessment, and management of forest pests. Through this special issue, we expect to contribute towards the improvement of our knowledge of the structures and processes in forest ecosystems relating to forest pests and fundamental information for the effective management of forest pests.
\end{abstract}

Keywords: climate change; forest ecosystem; forest pests; invasive species; monitoring

\section{Introduction}

Forest pests, including insects and microorganisms, are considered a regulating factor in the nutrient cycling and energy flow in forest ecosystems [1]. Among them, some species can cause severe damage to forest natural resources, resulting in serious changes in both the structures and functions of forest ecosystems. Forest pests have diverse negative impacts on forestry economy, ecosystem services, biodiversity, and sustainable ecosystem management, which are mostly related with alien species [2]. The first step towards effectively managing forest pests would be to monitor their occurrence and assess their impacts. The monitoring results can provide basic information for effective management strategies. For example, in North America the strategy for the gypsy moth, Lymantria dispar L., was constructed on the basis of the long-term monitoring of the range expansion of the gypsy moth [3]. In particular, long-term monitoring programs concerning forest pests offer an insight into their outbreaks, which is fundamental for the effective management of ecosystems [4]. The results of long-term monitoring programs can provide information concerning the occurrence patterns of forest pests. The data from monitoring programs can result in the development of new methods for monitoring, assessing impacts, and developing management techniques.

Forest pest monitoring programs have been intensively conducted in many countries, including the USA and European countries [5]. In the USA, the status of major forest pests, such as the gypsy moth, mountain pine beetle (Dendroctonus ponderosae (Hopkins)), and southern pine beetle (Dendroctonus frontalis (Zimmermann)), along with risk maps for the major insects and diseases, are offered on a web 
site (https://www.fs.fed.us). Using long-term monitoring data, analyses of the population dynamics relating to an outbreak of forest insect pests are widely attempted [6]. The stratified dispersal of the gypsy moth was elucidated based on long-term monitoring of the dispersal of the moth [3]. Long-term monitoring data of pine-defoliating lepidopteran pests, including Dendrolimus pini L., Hyloicus pinastri L., and Bupalus piniarius L., in pine forests from 1880 to 1940 were recorded and used for clarifying the periodicity in the occurrence of these pests [4]. The occurrence of the pine processionary moth (Thaumetopoea pityocampa (Denis and Schiffermuller)), observed from 1981 on permeant plots in France, displayed periodicity in a range of 7 to 11 years [7].

The monitoring program of forest pests in Korea, which has been conducted for both insect pests and pathogens since 1968 [4,8], consists of monitoring for major and occasional forest pests. The major pests selected for monitoring have been changed according to the damage severity of the pests [4]. For example, the pine caterpillar (Dendrolimus spectabilis (Butler)) was one of the main insect pests that were monitored from the 1960s to 1980s. However, it was removed from the monitoring list in 2016 due to the decline in its population. Currently, five major pests, including pine wilt disease (PWD) caused by pine wood nematodes; pine needle gall midge (PNGM) (Thecodiplosis japonensis (Uchida and Inouye)); black pine bast scale (Matsucoccus matsumurae (Kuwana)); Korean oak wilt disease caused by Raffaelea quercus-mongolicae (K.H. Kim, Y.J. Choi, and H.D. Shin); and fall webworm (Hyphantria cunea (Drury)), are monitored for their distribution, damage areas, or densities.

The occurrence of forest pests is influenced by various intrinsic and extrinsic factors [4]. The effective evaluation of the impacts of pests on the target ecosystems is important for forest ecosystem management. In particular, it is crucial to identify and assess the impacts of invasive species, to control their dispersal and delimitate the invasive species $[9,10]$. For example, tools have been developed to identify nematode species, for the rapid and exact diagnosis of pine wood nematodes in pine wood [11]. The classification of dispersal types, according to the invasive history of the pine wilt disease, offered insights for developing management strategies [9]. Meanwhile, diverse hazard rating systems have been developed to evaluate the potential distribution area and economic/ecological impacts of the invasive forest species, such as PNGM, black pine bast scale, and PWD [12-14].

An assessment of the relationship between environmental factors and forest pests provides fundamental information on their occurrence and abundance, which is essential for decision making concerning management strategies. Therefore, many studies have been conducted on the impacts of environmental factors on the occurrence of forest pests. For example, Kurz et al. [15] reported that both an increase in the winter temperature, due to recent climate change, and the uniform age structure of forests with older trees caused an outbreak of the mountain pine beetle (Dendroctonus ponderosae (Hopkins)) in British Columbia, Canada. The higher precipitation in August and drought during spring were key factors that reduced the population density of the pine caterpillar and PNGW, respectively $[8,16]$. Temperature is a limiting factor for determining the geographical distribution of Monochamus alternatus and Monochamus saltuarius, vectors for PWD in Korea [17].

The development of effective methods for managing forest pests is important for reducing the impacts of forest pests. The new methods can be developed based on theoretical approaches, with modelling and simulations for policy decision making, and can be tested and implemented through practical field applications. Information that is required for decision making is provided through hazard ratings, the examination of the potential economic and ecological impacts, the prediction of dispersal patterns for forest pests, etc. Models can simulate natural conditions to understand the causes of occurrence and decline of forest pests and evaluate the influence of various environmental factors.

This special issue ("Impacts, Monitoring, and Management of Forest Pests and Diseases") aims to share information to assist in the effective management of forest pests, by understanding the responses of forest pests to natural and anthropogenic changes, and discussing new studies on the monitoring, assessment, and management of forest pests. 


\section{Papers in this Issue}

The thirteen papers included in this issue focus on monitoring, assessing, and managing forest pests (Table 1). Choi et al. [4] reviewed changes in major forest pests, specifically, insect pests of pine forests in Korea over the last 50 years, and presented the shift in pests from the pine needle gall midge to the pine wilt disease due to changes in the forest structure. Meanwhile, Sierota et al. [18] reported on changes in the health of forests and their biological diversity in Poland over the last 30 years, by considering the climate, species composition, impacts of forest pests, forest management, etc. They concluded that forests in Poland are highly diversified but vulnerable to outbreaks of forest pests.

In this special issue, four papers focused on the monitoring of forest pests. Choi et al. [19] revised the taxonomy of the Japanese pine bast scale, Matsucoccus matsumurae (Kuwana), which had been described as Matsucoccus thunbergii by Miller and Park [20], based on morphological and DNA sequence analyses. They also updated the occurrence distribution of this species. Jennings et al. [21] compared two methods (visual survey and bark shifting) for monitoring the establishment of Oobius agrili (Zhang and Huang), which is a parasitoid on the emerald ash borer (Agrilus planipennis (Fairmaire)), an invasive species in Maryland, USA. They concluded that visual surveying was more efficient than bark shifting. Meanwhile, Mora-Sala et al. [22] demonstrated the efficiency of qPCR approaches to determine the presence and distribution of Phytophthora sp. in holm oak areas. In a study on the top-down attack pattern of Tomicus brevipilosus on Pinus kesiya, Liu et al. [23] reported that the initial attack location and aggregation pheromones were important for mediating the aggressive behavior and top-down attack pattern.

Meanwhile, three papers focused on the assessment of forest pests. Soares et al. [24] studied eucalyptus defoliation caused by the fungus Calonectria pteridis. They reported that the defoliation varied according to the doses of calcium ( $\mathrm{Ca}$ ) and potassium $(\mathrm{K})$. An imbalance of $\mathrm{Ca}$ and $\mathrm{K}$ favors leaf blight and defoliation caused by the fungus in Eucalyptus plants, indicating the need for a balanced supply of $\mathrm{Ca}$ and $\mathrm{K}$, to reduce the disease severity and defoliation. Zhang et al. [25] studied the differences in the trapping effects of Semanotus bifasciatus between two populations (Beijing and Shandong), based on next-generation sequencing, by analyzing the antennal transcriptome of both sexes of S. bifasciatus from the two populations. They found that the expression levels of odorant binding proteins, odorant receptors, and sensory neuron membrane proteins in males were lower in the Beijing population than in the Shandong population. Szmidla et al. [26] studied the threat of root-feeding Melolonthinae larvae on scots pine plantations, and reported that the population size of Melolonthinae and location of the larvae were related to the weather conditions. Therefore, they recommended an assessment during spring instead of autumn, to properly assess the cockchafer threat.

Finally, four papers focused on the management of forest pests. Kamczyc et al. [27] studied Mesostigmata mite communities in the decomposed litter of broadleaved and coniferous trees, to evaluate the effects of the re-establishment of mixed or broadleaved forests with native species. The results revealed that the species richness and diversity of the mite community were not affected, but the mite abundance was influenced by the tree species, which suggests differences in the litter quality. They also proposed that the exposition time is an important driver in shaping the mite community during the early stages of litter decomposition. Lalik et al. [28] compared the efficacy of different attractants in pitfall traps to capture the large pine weevil, Hylobius abietis (Linnaeus), which is the main pest of coniferous seedlings in Europe. They reported that the pitfall traps with attractants of pine twigs and ethanol are useful for monitoring and controlling H. abietis. Baek et al. [29] evaluated the current and future distribution of Ricania shantungensis (Chou and $\mathrm{Lu}$ ), which is an invasive planthopper and an important pest in agriculture and forestry in Korea [30], using CLIMEX and the Maximum Entropy Model (MaxEnt). In the MaxEnt, the most important variables determining the distribution of $R$. shantungensis were the annual mean temperature, mean temperature of the coldest month, maximum temperature in the warmest month, and precipitation of the driest month. The study concluded that the probability of occurrence of this species is higher in western areas than in eastern areas of Korea, with great potential to spread eastward. Finally, Lee et al. [31] predicted the potential distribution of 
the citrus Flatid planthopper, Metcalfa pruinosa (Say), which is an invasive species in many countries, based on the gradient of environmental conditions using a random forest model. Their results show that factors relating to human activities strongly influence the occurrence and dispersal of the citrus Flatid planthopper, which has a high potential to disperse over the whole of South Korea.

Table 1. List of papers included in the special issue.

\begin{tabular}{|c|c|c|c|}
\hline Category & Organism & Title & Authors \\
\hline \multirow[t]{2}{*}{ Review } & Insects and nematodes & Changes in major insect pests of pine forests in Korea over the last 50 years & Choi et al. [4] \\
\hline & Forests & $\begin{array}{l}\text { Abiotic and biotic disturbances affecting forest health in Poland over the past } 30 \\
\text { years: Impacts of climate and forest management }\end{array}$ & Sierota et al. [18] \\
\hline \multirow[t]{4}{*}{ Monitoring } & Insect & $\begin{array}{l}\text { Review of Japanese pine bast scale, Matsucoccus matsumurae (Kuwana) } \\
\text { (Coccomorpha: Matsucoccidae), occurring on Japanese black pine (Pinus } \\
\text { thunbergii Parl.) and Japanese red pine (P. densiflora Siebold \& Zucc.) from Korea }\end{array}$ & Choi et al. [19] \\
\hline & Insect & $\begin{array}{l}\text { Comparing methods for monitoring establishment of the emerald ash borer } \\
\text { (Agrilus planipennis, Coleoptera: Buprestidae) egg parasitoid Oobius agrili } \\
\text { (Hymenoptera: Encyrtidae) in Maryland, USA }\end{array}$ & Jennings et al. [21] \\
\hline & Insect & $\begin{array}{l}\text { Initial location preference together with aggregation pheromones regulate the } \\
\text { attack pattern of Tomicus brevipilosus (Coleoptera: Curculionidae) on Pinus kesiya }\end{array}$ & Liu et al. [23] \\
\hline & Pathogen & $\begin{array}{l}\text { The use of qPCR reveals a high frequency of Phytophthora quercina in two Spanish } \\
\text { holm oak areas }\end{array}$ & Mora-Sala et al. [22] \\
\hline \multirow[t]{3}{*}{ Assessment } & Pathogen & $\begin{array}{l}\text { Calcium and potassium imbalance favours leaf blight and defoliation caused by } \\
\text { Calonectria pteridis in eucalyptus plants }\end{array}$ & Soares et al. [24] \\
\hline & Insect & Chemosensory characteristics of two Semanotus bifasciatus populations & Zhang et al. [25] \\
\hline & Insect & $\begin{array}{l}\text { The spring assessing method of the threat of Melolontha spp. grubs for scots pine } \\
\text { plantations }\end{array}$ & Szmidla et al. [26] \\
\hline \multirow[t]{4}{*}{ Management } & Insect & $\begin{array}{l}\text { Mite communities (Acari, Mesostigmata) in the initially decomposed 'litter } \\
\text { islands' of } 11 \text { tree species in scots pine (Pinus sylvestris L.) forest }\end{array}$ & Kamczyc et al. [27] \\
\hline & Insect & $\begin{array}{l}\text { Simple is best: Pine twigs are better than artificial lures for trapping of pine } \\
\text { weevils in pitfall traps }\end{array}$ & Lalik et al. [28] \\
\hline & Insect & $\begin{array}{l}\text { Current and future distribution of Ricania shantungensis (Hemiptera: Ricaniidae) } \\
\text { in Korea: Application of spatial analysis to select relevant environmental } \\
\text { variables for MaxEnt and CLIMEX modeling }\end{array}$ & Baek et al. [29] \\
\hline & Insect & $\begin{array}{l}\text { Occurrence prediction of the citrus Flatid planthopper (Metcalfa pruinosa (Say, } \\
\text { 1830)) in South Korea using a random forest model }\end{array}$ & Lee et al. [31] \\
\hline
\end{tabular}

\section{Conclusions}

Global change and increases in human activities induce changes in the habitats of various organisms, including plants and animals, resulting in a reduction in ecosystem stability and increased outbreaks of insect pests and pathogens. In many countries, most forest pests are currently invasive species, causing huge negative impacts on both economic and ecological aspects. To minimize the impacts and effectively control them, the appropriate systems for monitoring, assessing, and managing forest insect pests and diseases are essential. We believe that this special issue provides a better understanding of the structures and processes in forest ecosystems and fundamental information for the effective management of forest pests.

Author Contributions: Conceptualization, W.I.C. and Y.-S.P.; writing-original draft preparation, W.I.C. and Y.-S.P.; writing-review and editing, W.I.C. and Y.-S.P.

Funding: This study was supported by the National Institute of Forest Science and R \& D Program for Forest Science Technology (FTIS 2017042A00-1823-CA01) provided by Korea Forest Service (Korea Forestry).

Acknowledgments: We would like to thank all contributors in this special issue and all reviewers who provided very constructive and helpful comments to evaluate and improve the manuscripts.

Conflicts of Interest: The authors declare no conflict of interest. The funders had no role in the design of the study; in the collection, analyses, or interpretation of data; in the writing of the manuscript, or in the decision to publish the results.

\section{References}

1. Hobbie, S.E.; Villeger, S. Interactive effects of plants, decomposers, herbivores, and predators on nutrient cycling. In Trophic Ecology: Bottom-Up and Top-Down Interactions across Aquatic and Terrestrial System; Hanley, T.C., Pierre, K.J.L., Eds.; Cambridge University Press: Cambridge, UK, 2015; pp. 233-259. [CrossRef] 
2. Seidl, R.; Thom, D.; Kautz, M.; Martin-Benito, D.; Peltoniemi, M.; Vacchiano, G.; Wild, J.; Ascoli, D.; Petr, M.; Honkaniemi, J.; et al. Forest disturbances under climate change. Nat. Clim. Chang. 2017, 7, 395. [CrossRef] [PubMed]

3. Sharov, A.A.; Liebhold, A.M. Model of slowing the spread of gypsy moth (Lepidoptera: Lymantriidae) with a barrier zone. Ecol. Appl. 1998, 8, 1170-1179. [CrossRef]

4. Choi, W.I.; Nam, Y.; Lee, C.Y.; Choi, B.K.; Shin, Y.J.; Lim, J.-H.; Koh, S.-H.; Park, Y.-S. Changes in major insect pests of pine forests in Korea over the last 50 years. Forests 2019, 10, 692. [CrossRef]

5. Potter, K.M.; Conkling, B.L. Forest Health Monitoring: National Status, Trends, And Analysis 2017; Southern Research Station: Asheville, NC, USA, 2018.

6. Turchin, P.; Taylor, A.D. Complex dynamics in ecological time series. Ecology 1992, 73, 289-305. [CrossRef]

7. Li, S.; Daudin, J.J.; Piou, D.; Robinet, C.; Jactel, H. Periodicity and synchrony of pine processionary moth outbreaks in France. For. Ecol. Manag. 2015, 354, 309-317. [CrossRef]

8. Choi, W.I.; Park, Y.-S. Dispersal patterns of exotic forest pests in South Korea. Insect Sci. 2012, 19, 535-548. [CrossRef]

9. Choi, W.I.; Song, H.J.; Kim, D.S.; Lee, D.-S.; Lee, C.-Y.; Nam, Y.; Kim, J.-B.; Park, Y.-S. Dispersal patterns of pine wilt disease in the early stage of its invasion in South Korea. Forests 2017, 8, 411. [CrossRef]

10. Lee, D.-S.; Nam, Y.; Choi, W.I.; Park, Y.-S. Environmental factors influencing on the occurrence of pine wilt disease in Korea. Korean J. Ecol. Environ. 2017, 50, 374-380. [CrossRef]

11. Cha, D.J.; Kim, D.S.; Lee, S.K.; Han, H.R. A new on-site detection method for Bursaphelenchus xylophilus in infected pine trees. For. Pathol. 2019, 49, e12503. [CrossRef]

12. Park, Y.-S.; Chung, Y.-J. Hazard rating of pine trees from a forest insect pest using artificial neural networks. For. Ecol. Manag. 2006, 222, 222-233. [CrossRef]

13. Nam, Y.; Koh, S.-H.; Jeon, S.-J.; Youn, H.-J.; Park, Y.-S.; Choi, W.I. Hazard rating of coastal pine forests for a black pine bast scale using self-organizing map (SOM) and random forest approaches. Ecol. Inform. 2015, 29, 206-213. [CrossRef]

14. Park, Y.-S.; Chung, Y.-J.; Moon, Y.-S. Hazard ratings of pine forests to a pine wilt disease at two spatial scales (individual trees and stands) using self-organizing map and random forest. Ecol. Inform. 2013, 13, 40-46. [CrossRef]

15. Kurz, W.A.; Dymond, C.C.; Stinson, G.; Rampley, G.J.; Neilson, E.T.; Carroll, A.L.; Ebata, T.; Safranyik, L. Mountain pine beetle and forest carbon feedback to climate change. Nature 2008, 452, 987-990. [CrossRef] [PubMed]

16. Hyun, J.S. Studies on the prevision for occurrence of pine moth, Dendrolimus spectabilis Butler. Ent. Res. Bull. $1968,4,57-80$.

17. Kwon, T.S.; Lim, J.H.; Sim, S.J.; Kwon, Y.D.; Son, S.K.; Lee, K.Y.; Kim, Y.T.; Park, J.W.; Shin, C.H.; Ryu, S.B.; et al. Distribution patterns of Monochamus alternatus and M. saltuarius (Coleoptera: Cerambycidae) in Korea. J. Korean For. Soc. 2006, 95, 543-550.

18. Sierota, Z.; Grodzki, W.; Szczepkowski, A. Abiotic and biotic disturbances affecting forest health in Poland over the past 30 years: Impacts of climate and forest management. Forests 2019, 10, 75. [CrossRef]

19. Choi, J.; Cha, D.; Kim, D.-S.; Lee, S. Review of Japanese pine bast scale, Matsucoccus matsumurae (Kuwana) (Coccomorpha: Matsucoccidae), occurring on Japanese black pine (Pinus thunbergii Parl.) and Japanese red pine (P. densiflora Siebold \& Zucc.) from Korea. Forests 2019, 10, 639. [CrossRef]

20. Miller, D.R.; Park, S.-C. A new species of Matsucoccus (Homoptera: Coccoidae: Margarodidae) from Korea. Korean J. Plant. Prot. 1987, 26, 49-62.

21. Jennings, D.E.; Duan, J.J.; Shrewsbury, P.M. Comparing methods for monitoring establishment of the emerald ash borer (Agrilus planipennis, Coleoptera: Buprestidae) egg parasitoid Oobius agrili (Hymenoptera: Encyrtidae) in Maryland, USA. Forests 2018, 9, 659. [CrossRef]

22. Mora-Sala, B.; Berbegal, M.; Abad-Campos, P. The use of qPCR reveals a high frequency of Phytophthora quercina in two Spanish holm oak areas. Forests 2018, 9, 697. [CrossRef]

23. Liu, F.; Wu, C.; Zhang, S.; Kong, X.; Zhang, Z.; Wang, P. Initial location preference together with aggregation pheromones regulate the attack pattern of Tomicus brevipilosus (Coleoptera: Curculionidae) on Pinus kesiya. Forests 2019, 10, 156. [CrossRef] 
24. Soares, T.P.F.; Pozza, E.A.; Pozza, A.A.A.; Mafia, R.G.; Ferreira, M.A. Calcium and potassium imbalance favours leaf blight and defoliation caused by Calonectria pteridis in Eucalyptus plants. Forests 2018, 9, 782. [CrossRef]

25. Zhang, S.; Shen, S.; Zhang, S.; Wang, H.; Kong, X.; Liu, F.; Zhang, Z. Chemosensory characteristics of two Semanotus bifasciatus populations. Forests 2019, 10, 655. [CrossRef]

26. Szmidla, H.; Małecka, M.; Tkaczyk, M.; Tarwacki, G.; Sierota, Z. The spring assessing method of the threat of Melolontha spp. grubs for Scots pine plantations. Forests 2019, 10, 399. [CrossRef]

27. Kamczyc, J.; Dyderski, M.K.; Horodecki, P.; Jagodziński, A.M. Mite communities (Acari, Mesostigmata) in the initially decomposed 'litter islands' of 11 tree species in Scots pine (Pinus sylvestris L.). Forests 2019, 10, 403. [CrossRef]

28. Lalík, M.; Holuša, J.; Galko, J.; Resnerová, K.; Kunca, A.; Nikolov, C.; Mudrončeková, S.; Surový, P. Simple is best: Pine twigs are better than artificial lures for trapping of pine weevils in pitfall traps. Forests 2019, 10, 642. [CrossRef]

29. Baek, S.; Kim, M.-J.; Lee, J.-H. Current and future distribution of Ricania shantungensis (Hemiptera: Ricaniidae) in Korea: Application of spatial analysis to select relevant environmental variables for MaxEnt and CLIMEX modeling. Forests 2019, 10, 490. [CrossRef]

30. Baek, S.; Koh, S.-H.; Lee, J.-H. Occurrence model of first instars of Ricania shantungensis (Hemiptera: Ricaniidae). J. Asia-Pac. Entomol. 2019, 22, 1040-1045. [CrossRef]

31. Lee, D.-S.; Bae, Y.-S.; Byun, B.-K.; Lee, S.; Park, J.K.; Park, Y.-S. Occurrence prediction of the citrus flatid planthopper (Metcalfa pruinosa (Say, 1830)) in South Korea using a random forest model. Forest 2019, 10, 585. [CrossRef]

(C) 2019 by the authors. Licensee MDPI, Basel, Switzerland. This article is an open access article distributed under the terms and conditions of the Creative Commons Attribution (CC BY) license (http://creativecommons.org/licenses/by/4.0/). 